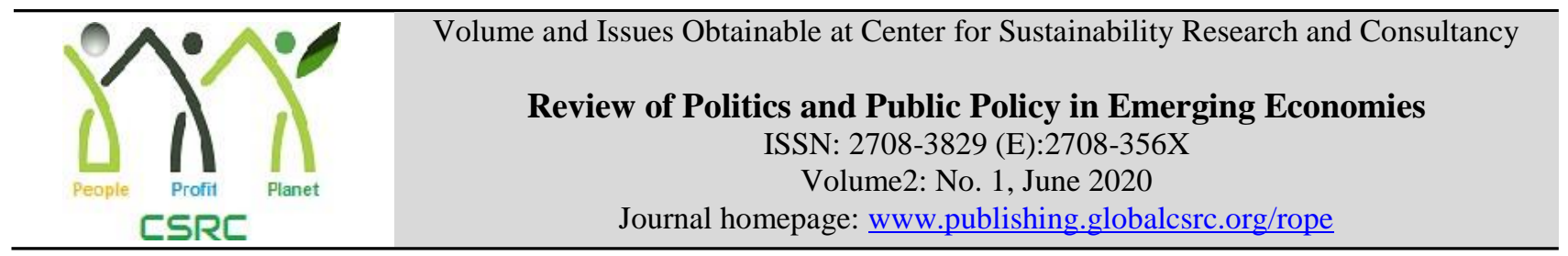

\title{
Political and Economic Impacts of Brexit on UK
}

\section{${ }^{1}$ Ghulam Mustafa, ${ }^{2}$ MazharHussain, ${ }^{3}$ Muhammad Adnan Aslam}

${ }^{1}$ Assistant Professor, Department of Political science and International Relations, Government College University Faisalabad, Pakistan, ghulammustafa@gcuf.edu.pk

${ }^{2 \& 3}$ Mphil, Department of Political science and International Relations, Government College University Faisalabad, Pakistan

\begin{tabular}{l}
\hline ARTICLEDETAILS \\
\hline History \\
Revised format: May 2020 \\
Available Online: June 2020
\end{tabular}

\section{Keywords}

Brexit, UK, EU, Economic

impacts

\section{JEL Classification}

$F 5, F 50$

\begin{abstract}
Brexit is a term used to explain about the departure or withdrawal of Great Britain from the European Union. Brexit is a very important political development of recent political scenario of Europe. It has its impacts on the economic and political future of both UK and EU. The UK is enjoying membership of the EU from the beginning. But in mid of 2016 a referendum was held in UK to decide whether they should remain in EU or exit. The British people decide in favor of exit with a simple majority of $51.9 \%$. After that referendum British Prime Minister David Cameron resigned and new general elections were held in 2017. Since the referendum the UK and EU are negotiating on an exit deal and the UK is due to leave the union on 29th March 2019. It will have its dimensions and implications. There are voices rose demanding a new referendum on the issue because many British people think that the Brexit is not good for UK. There are pro EU voices in European countries who also wish UK to remain part of this community. In this descriptive study 'impacts of Brexit on UK' has been discussed and economic and political dimensions have been observed by the researchers.
\end{abstract}

(C) 2020The authors, under a Creative Commons Attribution-Non Commercial

\section{OPEN ACCESS}

Corresponding author's email address: ghulammustafa@ gcuf.edu.pk

Recommended citation: Mustafa, G., Hussain, M. and Aslam, M.A. (2020). Political and Economic Impacts of Brexit on UK. Review of Politics and Public Policy in Emerging Economies, 2(1),1-08

\section{Introduction}

Brexit is a very important political development in the history of the UK and European Union. It will have its impacts on both UK and EU. It will affect the politics and economy of the Europe. In this study these impacts have been discussed and analyzed in detail. The political impacts of Brexit on UK are domestic and international. The domestic politics of UK has been affected and the ratification of withdrawal agreement has become controversial as the British Parliament has not agreed on the solutions which caused uncertainties. The international impacts are also very important on UK's relations with other countries. Most importantly the issue of Ireland has become very difficult as it is 
relevant to both domestic and international politics.

The Irish issue is complex because of Northern Ireland and post Brexit relations of UK with Republic of Ireland which is a member state of EU. UK had negotiated a withdrawal agreement with EU which covers many important issues and the post Brexit relations of UK with EU. The withdrawal agreement had been ratified by the EU institutions but it has not been ratified by the British Parliament which is a requirement for the approval of the agreement. So the chances of no deal Brexit have increased. The Spain had also its reservations over Gibraltar. The health and social care systems of UK will also be affected by the Brexit.

The UK will also be affected in terms of economy. UK has very close economic relations with EU countries. UK's exports and imports will be affected. The UK is currently enjoying the single market benefits which cannot be available after its withdrawal of the membership of the union. UK has tried during the negotiations to retain the benefits while having access to the single market, but EU officials had made it clear that the four freedoms are indivisible and UK can only have access to the single market by remaining a full member.

Brexit will also adversely affect the foreign direct investments to the UK, because it was a center point for the foreign investors as a member state of the EU. Property market of the UK will also be affected. The impacts of Brexit can also be observed on the stock market of the UK. The currency of the UK will be affected and it has already devalued since the referendum. The financial institutions such as banks and insurance companies will be affected by the Brexit.

\subsection{Hypothesis}

H1: The UK will be affected politically and economically by the Brexit more than EU.

$\mathrm{H} 2$ : EU will remain stable even after Brexit despite of some challenges.

\subsection{Research Objectives}

The objectives of this research are to discuss and analyze the impacts of the Brexit on UK and EU. It is an ongoing and current affair and it requires continuous analyses. No study or research can be conclusive on this issue. It has many dimensions and implications. In this study only political and economic dimensions have been discussed. It has been discussed that how Brexit affected the domestic politics of UK, its international relations and its economy.

This research also aimed to discuss the impacts of Brexit on EU. The Brexit will also affect the EU, its politics and its economy. So by reviewing the available literature and political and economic developments the impacts on the EU has been analyzed. Its objective is to assess as to which extent the EU will be affected by the Brexit. There are certain challenges for the EU caused by the Brexit. It will be assessed and observed that whether EU will remain stable despite of the challenges.

\subsection{Significance of the Study}

The significance of this study is very high. The Brexit is the most important political development in the Europe since the Second World War. As the Brexit referendum was held in 2016 and now more than three years have been passed but it is not yet clear that what is going to happen next. It has become dramatic. So no research on this phenomenon can be said conclusive. The dynamics in the British political system has been changed. The new political parties have taken their space not only in UK but also in the EU. Right wing political parties are emerging on the political screen in Europe. Furthermore, the already settled issues in UK such as Northern Ireland and Scotland are once again arisen in UK, causing serious political challenges for UK to maintain its national unity. Anti-immigrant or in other words xenophobic waves are also there in both UK and EU.

Besides these political impacts Brexit have its certain impacts on economies of UK and EU. It will have 
very seriously adverse effects on the imports and exports between UK and EU. UK intended to be a part of EU's single market to avoid tariffs over goods and services but EU blatantly refused it. In such circumstances most probably UK will have to trade with EU under WTO tariffs. These Tariffs will increase the burden on UK's economy. UK's GDP will also shrink. Foreign Direct investments will be reduced; the UK's currency's value will also be reduced. So the past three years have certainly proved that Brexit has not been a good option as yet for the UK and it is also less likely to do any good in coming years. It has created many political and economic challenges for the UK and EU.

This study is focusing on these political and economic challenges and it would be a good addition to the literature on this particular subject. It would be useful not only for academia but also for the think tanks. The certain facts and different possible scenarios have been observed in this study after reviewing the valuable literature of various institutions and scholars. This study is not so complex and it could be understood even by a common man. Brexit is a current affair and this study would also be helpful for further research. The significance of this study is higher also because it covers various dimensions and implications of this political phenomenon. The recommendations have also been given in the end of this study.

\subsection{Research Methods}

In this study qualitative research method is applied by collecting, researching and analyzing secondary data sources (newspapers, books, articles, journals, government records, reports, statements of political leaders and government officials, etc.). The research work is analytical and descriptive and goes through the lens of different schools of thought. It is a current affair and newspapers, articles and governmental records and statements of officials available on internet will be considered for deduction of facts and reasons supporting this study. Furthermore, the results and concepts have been discussed and explained qualitatively.

\section{Theoretical Framework}

\subsection{Nationalism}

Theory of nationalism was developed by Ernest Gellner. Nationalism means that it is a desire of a nation to be politically independent and make their decisions by themselves (Cambridge Dictionary). So in this case this theory of nationalism applies because English people have decided through a referendum that they want to exit from the EU. Because they think they should make their decisions without any intervention of the union. So the nationalist desire is one of the main factors which caused Brexit.

In last three years the English nationalism has risen and liberal forces have been pushed back. The leave voters in 2016's referendum have preferred their English identity. The English people want to take back control of their borders, their economy and their welfare system. The Brexit is a phenomenon which is English-centric; it does not address the concerns of Northern Ireland, Wales and Scotland. However; the Issue of Northern Ireland has become complicated afterwards (Denham, 2019). The whole process is seemed to be dominated by English nationalism and nationalists.

\subsection{Xenophobia}

Xenophobia means fear and hatred of strangers or foreigners or of anything that is strange or foreign (Kirkpatrick, 2020). It is also applicable to Brexit. The fear of foreigners or immigrants was one of the main factors which driven voters to vote for leave in Brexit referendum. It is a psychological factor which had its impacts on the political circumstances. The increased support to leave the EU is associated with this psychological factor.

The researchers have examined three groups of Brexiteers, right-wing authoritarianism and social dominance orientation and third group is collective narcissism. It is a belief in the greatness of own country. It was also observed that the Brexit was also supported by the nationalist far right leaders 
like Trump, Vladimir Putin. These three personality traits have their relation to Xenophobia which consequently increased support for Brexit. The study was quantitative and was conducted on two different occasions, the first was conducted just after the referendum and the second was in September 2016 through an online questionnaire. 280 people participated in first and 226 in the second (Gabbatiss, 27).

Chair of the European Commission against Racism and Intolerance Christian Ahlund stated that antiforeigner sentiment will arise further after the Brexit referendum. Dr Golec de Zavala who conducted this study stated that the leave campaign was a new and acceptable way to express Xenophobia (Adler, 2016).The people have expressed their xenophobic sentiments through leave campaign and the results of referendum also show that such people are in majority even this psychological element was not the sole issue of leave campaign but it was one of the most important issues.

\section{Review of Literature}

How to stop Brexit: And make Britain great again book is written by Nick Clegg who was the Deputy Prime Minister of UK. In this book the writer argued in favor of remaining in EU, he tried to reveal that British people had not the accurate information at the time of referendum was held and he favored another vote on the issue and suggested that it would not hurt democracy of UK. But he pointed out that it may have some positive impacts to reform which may be beneficial for the European Union (Clegg, 2017).

Tony Connelly a European correspondent for RTE in Brussels. This book he termed Brexit as a shock for the neighbors of Britain the Irish people. For Ireland the Brexit is the greatest challenge after 2nd world War to its economy and foreign policy. Brexit is the highest political upset of 21 st century in Europe. It is affecting many EU countries and Ireland will be affected more than any other country except UK. The writer has also discussed the opportunities and the story of inside Irish response on Brexit (Connelly, 2017).

William Outhwaite the writer discussed in this book the social aspects and impacts of Brexit on UK and other countries. He examined the revival of class politics in UK, the voters who belong to working-class swung right and not left. It also suggested the weakness of the union as it already failed to gain public support from Norway and Switzerland to become members of EU. The UK was already not fully attached with EU in terms of currency (Euro) and Schengen zone as UK opted out of both of them. The Brexit has strengthened the right wing politics and populist and nationalist politics (Outhwaite, 2017).

Beyond Brexit? How to Assess the UK's Future is written by Janice Morphet. In this book the writer has discussed the impacts of Brexit on policy and its uncertainty. The writer tried to analyze the future action plan and institutional options post-Brexit. It also focused on the negotiations between UK and EU to reach a deal for Brexit. She also had thrown light on the possible future behavior and policies of EU towards UK. It has also been discussed the impacts of Brexit on devolved nations of UK and Ireland (Morphet, 2017).

Craig Oliver has worked closely to ex-Prime Minister of UK David Cameron as Downing Street Director of Communications from 2011 to 13th July 2016 so he was aware what was actually happening inside before and after Brexit. In this book he has discussed about the responsibility of the failure of referendum plan of the government which resulted in the resignation of PM David Cameron and his cabinet. The writer also criticized PM for let the referendum happen as the results of referendum were unwanted (Oliver, 2017).

\subsection{Historical Background}

There is a history of relationship between UK and EU. The Treaty of Paris was signed by France, 
Belgium, Italy, West Germany, Netherlands and Luxembourg in 1951. This treaty established the European Coal and Steel Community. It was a practical start which leads to present European Union. After $2^{\text {nd }}$ World War it was an important step towards economic stability of European nations. In 1961 UK applied for the first time for the membership of EEC but that request was vetoed by the then French President Charles de Gaulle. UK applied again for the membership in 1963 and it was vetoed again by France in 1967. In 1969 UK received positive signals to negotiate the membership of UK (The UK in a Changing Europe, 2019). The French President vetoed British applications because of economic conditions and circumstances of UK (Paul Goldsmith, 2017).

The UK succeeded to be its member in 1973 but after only two years UK held a referendum on $5^{\text {th }}$ June 1975 and the question was: "Do you think the UK should stay in the European Community. The 67\% voted in favor of 'Yes'. The tensions between UK and EEC reached its peak in 1984. The British PM Margaret Thatcher had tough talk with EEC on the issue of British part of payments in the ECC budget because Britain was paying more than other EEC members because of their lack of farms, despite being $3^{\text {rd }}$ poorest nation in the community (Morphet, 2017). In 2011, the British PM David Cameron vetoed the EU treaty which was aimed to tackle the crisis in Euro zone and became first British PM to do so. In 2013, David Cameron promised to renegotiate the membership in the EU. The support to leave the EU was increased because of economic unrest of Eurozone and migrant crisis, and far right political party UKIP (United Kingdom Independence Party) also supported to leave the EU (Justin O. Frosini, 2019).

\subsection{Impacts of Brexit on Domestic Politics of UK}

Brexit has been proven as catastrophic for domestic politics of UK as yet. There is ongoing chaos and divide in British Parliament. British political parties are even divided from inside and there is a divide in British public as well. The leadership has failed to lead the nation in a certain way. The Brexit referendum has triggered a series of political events in UK. The very first outcome of Brexit referendum was the resignation of the UK's Prime Minister David Cameron from his office. He has served for six years in his office and his political career finished with the outcome of Brexit referendum as leave won the referendum. Before Brexit referendum David Cameron had tried his best to convince British people vote for remain because leaving the European Union would be an economic self-harm but the results of referendum were shocking for Cameron.

Thressa May became the UK's Prime Minister on $13^{\text {th }}$ July 2016. She became the Second female PM after Margaret Thatcher in British history. On 29 $9^{\text {th }}$ March 2017 UK officially triggered article fifty of the Lisbon Treaty and then the countdown started of two years as after invoking Article fifty the UK set to officially leave the union on $29^{\text {th }}$ March 2019 . There are certain processes which have to be took place during these two years. The talks between UK and EU officials have to be started and UK has to negotiate with other EU countries as well. When all the parties will reach on the deal then it would require the ratifications from EU (72\% of $27 \mathrm{EU}$ countries or representing $65 \%$ population) and British parliaments (Sheena Mckenzie, 2016).

\subsection{Brexit Deal of UK with EU}

Mrs. May wrote and signed a letter in which she officially triggered Article 50, she also indicated seven principles of negotiations.

1. UK and EU should engage respectfully and constructively with a spirit of sincere cooperation.

2. UK and EU should work together to secure a comprehensive agreement.

3. UK and EU should always prioritize their citizens.

4. UK and EU should try to avoid confusion or chaos and try to ensure maximum certainty.

5. UK's special relations with Republic of Ireland would be kept in mind and Northern Ireland's peace process shall also be given special importance.

6. UK and EU should initiate discussions on policy areas in detail but the big challenges should be discussed first. 
7. The European values of both UK and EU should be protected and advanced and work should continue in this regard.

After a long process which took almost two years of negotiations UK and EU reached an agreement on the withdrawal of the UK and Northern Ireland from the EU and the European Atomic Energy Community. It was a comprehensive and composite agreement covering many areas including Border and immigration issues, legal issues, trade issues and other important issues covering UK and EU relations. According to article three of withdrawal agreement the territorial scope is defined and United Kingdom includes the territories of UK, Gibraltar, Channel Islands and Isle of Man, sovereign base areas of Dhekelia and Akrotiri in Cyprus. The withdrawal agreement is most important to understand the impacts of Brexit on UK and EU.

\subsection{Impacts of Brexit on Immigration and Free Movement}

Brexit has its impacts on immigration and free movement. At the moment when the Brexit process has not yet completed and until the transition period the free movement of British citizens to EU countries and EU citizens to UK exists. As UK is part of EU as yet so all the EU citizens and their Non-EU family members may live, work or study in any EU member state and they are not subject to general immigration rules of those member states. EU Directive 2004/38/EC is the law which regulates the residence of EU nationals in EU member states ( Europeon Parliment \& The Council, 2004).

According to the Directive EU citizens can enter all of its member states without an entry visa, and they can register themselves in any member state of the EU as a student, worker (employed or self-employed) or as a self-sufficient person. The member states issue such registered persons and their family members the residence card of five years and permanent residence after five years.

Now the post Brexit scenario regarding free movement of British and EU citizens between UK and EU member states has to be assessed and the impacts to be analyzed. The very first instrument which may be helpful to predict the future of free movement of British and EU citizens is withdrawal agreement. The significance of free movement can be seen as it has been mentioned in early part of withdrawal agreement. The withdrawal agreement protects the UK and EU citizens and their family members already exercising their right to reside in other EU states or will exercise before the end of transition period; they can continue their residence even after Brexit.

\subsection{Irish Backstop}

The Irish backstop is required to be discussed in detail because this sole issue is having full potential to undo all the Brexit process. There is a background and a multilateral agreement was signed between UK, Northern Ireland and the Government of Ireland, this agreement is Belfast agreement and also called Good Friday Agreement because it was signed on Good Friday. This agreement was signed on $10^{\text {th }}$ April 1998. After the agreement the referendums were held in Northern Ireland and in Republic of Ireland on $22^{\text {nd }}$ May 1998. These referendums endorsed the agreement changing Irish constitution and recognizing that the Northern Ireland will remain with UK. It was beginning of a new era after a long history of unrest in the region (Oliver, 2017).

\subsection{Impacts on British Exports to EU}

As the Brexit caused uncertainties in almost every sector of businesses in UK it also brought uncertainty on UK's exports to EU. The uncertainty creating fears in the minds of businesses and firms and consequently the investments have been deferred and these are very serious implications for UK's economy. The default position of UK is that it is heading towards a no deal Brexit as the withdrawal agreement between UK and EU could not approved by the British Parliament. The no deal Brexit will be lethal for UK's economy as they could lose tariff free access to their nearest and largest market. The UK exporters could face WTO rules and tariffs for trade with EU which will be higher as compared to no Brexit scenario (Meredith A. Crowley, 2019). 


\subsection{Impacts of Brexit on Foreign Direct Investments in UK}

Foreign direct investment is the investment which companies of foreign countries invest in the recipient country. It always considered very important for the economy of that recipient country and have implications in various sectors and create new jobs. UK attracts GBP 1 Trillion as FDI and almost half of it received by the EU member states. It seems that in case of Brexit the FDI will certainly decrease and will also have negative impacts on GDP. The main reason of such decrease is the new tariff plans after Brexit as UK will be out of EU's single market as well which will create difficulties for European based companies to directly invest in UK. The Brexit will certainly affect FDI because UK as a part of the union attracted reasonable amount of FDI because of flexible international trade system within EU with less restrictions on the movement of products which facilitated trade (Simionescu, 2016).

\section{Conclusion}

Keeping in view the above discussion it is concluded that Brexit had affected the British politics very deeply. It has its political impacts in various dimensions such as it had affected the domestic politics of UK. The one of the world's oldest parliament couldn't find a way to get out of it. The British political parties have been seemed to be divided from within. The withdrawal agreement has not been ratified. Growing uncertainty is another important issue as uncertainty alone has potential to disturb not only the political system but in other dimensions also.

Irish issue which was well settled between UK and Ireland has been evoked and Northern Ireland is the reason. Irish backstop which was part of withdrawal agreement has become controversial and also the main reason of withdrawal agreement being not approved by the parliament, and that's why the risk of no deal Brexit is more likely which is even more worsening. Brexit is also having its impacts on international relations of UK, because when it was in the union it was considered a very important player in the union. While remaining in the union UK was enjoying very close relationship with the twenty-seven European countries. UK was also having its representatives in European institutions such as European Commission, European Council and European Parliament, UK was having effective role in the decision making process of the EU.

\section{References}

Adler, K. (2016, October 4). Human rights report warns over 'anti-foreigner sentiment. Retrieved August 22, 2019, from BBC News: https://www.bbc.com/news/uk-politics-37539281

Clegg, N. (2017). How to stop Brexit: And make Britain great again. New York City: Random House. Connelly, T. (2017). Brexit and Ireland: The Dangers, the Opportunities, and the Inside Story of the Irish Response. London: Penguin Books Limited.

Denham, J. (2019, August 13). Nationalism in England is not just a rightwing nostalgia trip. Retrieved August 18, 2019, from The Guardian: https://www.theguardian.com/commentisfree/2019/aug/13/english-nationalism-brexit-remainand-reform

Europeon Parliment \& The Council. (2004, April 29). Directive 2004/38/EC of the Europeon Parliment and of the Council. Retrieved March 12, 2019, from eur-lex.europa: https://eurlex.europa.eu/legal-content/EN/TXT/?uri=CELEX\%3A32004L0038

Gabbatiss, J. (27, November 27). Brexit strongly linked to xenophobia, scientists conclude. Retrieved August 19, 2019, from Independent: https://www.independent.co.uk/news/science/brexit- 
prejudice-scientists-link-foreigners-immigrants-racism-xenophobia-leave-eu-a8078586.html

Justin O. Frosini, M. F. (2019). The Brexit car crash: using E.H. Carr to explain Britain's choice to leave the European Union in 2016. Tylor \& Francis , 22-33.

Kirkpatrick, N. (2020, February 9). Psychology Of Xenophobia And How It Affects Everyone. Retrieved February 18, 15, from Better Help: https://www.betterhelp.com/advice/phobias/psychology-ofxenophobia-and-how-it-affects-everyone/

Meredith A. Crowley, O. E. (2019, January 21). The impact of Brexit uncertainty on UK exports. Retrieved June 22, 2019, from VOXEU: https://voxeu.org/article/impact-brexit-uncertainty-ukexports

Morphet, J. (2017). Beyond Brexit?: How to Assess the UK's Future. Bristol: Policy Press .

Oliver, C. (2017). Unleashing Demons: The Inside Story of Brexit. London: Quercus Press.

Outhwaite, W. (2017). Brexit: Sociological Responses: Key Issues in Modern Sociology. New York: Anthem Press.

Paul Goldsmith, J. F. (2017, November 27). How President de Gaulle's second veto of Britain's EC application fifty years ago led directly to the Leave vote in 2016. Retrieved April 25, 2019, from The UK in a Changing Europe: https://ukandeu.ac.uk/how-president-de-gaulles-second-veto-ofbritains-ec-application-fifty-years-ago-led-directly-to-the-leave-vote-in-2016/

Sheena Mckenzie, E. C. (2016, July 14). Theresa May becomes new British Prime Minister. Retrieved April 19, 2019, from CNN News: https:/edition.cnn.com/2016/07/13/europe/theresa-may-davidcameron-british-prime-minister/index.html

Simionescu, M. (2016, July). The Impact of BREXIT on the Foreign Direct Investment in the United Kingdom. Bulgarian Economic Paper, 1-18. 